be observed, as far as possible, in each opposition of at least the brightest of these objects.

8. Commission 27 , though not prepared to extend its scope to the photometry of minor planets, recommends the observation of the brightness of asteroids to Variable Star observers.

By a formal vote, the Commission wished to congratulate heartily Dr R. Prager upon the completion of the first volume of the second edition of the Geschichte und Literatur des Lichtwechsels der veränderlichen Sterne. They also desired to record their appreciation of the important effort recently made by Russian astronomers in the field of Variable Star research, and their regret that one of the Commission's most active members, Mr G. B. Lacchini, had to direct his activity to other subjects.

With reference to the growth of photovisual photometry, the Commission considered that its application to the measurement of new sequences of comparison stars seemed desirable, but, despite the fact that certain observers found that photovisual sequences could be directly applied to visual observations, they thought that the question of the relation of the photovisual to the visual scale or scales - should be left open for the present. Mr Leon Campbell emphasized the need for distinguishing between both systems in all future publications where a doubt could arise about the system used.

In connection with the wish of the Harvard Members of the Commission that more photometric work with a simple type of photometer should be encouraged, Prof. Graff showed two types of small and inexpensive photometers which he has recently devised and constructed.

Prof. S. A. Mitchell described his work in the revision of 218 visual sequences, with altogether 6250 comparison stars, which he has recently completed and is about to publish. He announced his intention of observing visually the photovisual sequences of the Atlas Stellarum Variabilium, Part VIII.

The Commission voted that co-optation to its membership should not be limited, either to observers taking part in co-operative work, or to a certain number.

\title{
COMMISSION 28. (NEBULAE.)
}

\section{President: Dr H. Shapley. \\ SECRETARY: Dr J. H. OORT.}

Except for a brief discussion of the zero point of the period-luminosity curve and the influence of the absorption of light on its determination, the discussions were mainly confined to the draft report which was approved by the commission. The President read a report from Dr Lampland, which had not been included in the draft report and Prof. Lundmark gave an account of his work on extragalactic nebulae, in particular of the catalogue of about 50,000 nebulae which is now being prepared at Lund.

The President drew special attention to the importance of the problem of the spiral arms for future cosmogonic theories and urged further theoretical investigations on the origin of the spiral structures.

It was decided to defer the discussion of the spectrophotometry of nebulae to a joint meeting with Commission 36 , and that of the problems connected with stellar statistics to a joint meeting with Commission 33. 
The latter meeting was devoted to discussions on nebular magnitudes and on absorption.

The President drew attention to the importance of star counts in connexion with the magnitudes of extragalactic nebulae and urged the improvement and extension of the star count tables by van Rhijn and Seares and also an increase of the number of magnitude sequences between $+20^{\circ}$ and $-20^{\circ}$ galactic latitude; van Rhijn reported on the work done on the Selected Areas and pointed to the desirability of extending the counts in the southern areas. The improvement of the magnitude scales of the southern areas has already been taken in hand by Mrs Payne Gaposchkin.

Prof. Lindblad inaugurated a discussion of the problem of interstellar absorption, which was followed by a discussion between a number of the members. Among the principal desiderata for future work on this subject were mentioned: the determination of colours of extragalactic nebulae at different galactic latitudes, extension of systematic searches for Cepheid variables sufficiently bright to have their radial velocities determined, and an extension of intensity measures in the spectra of some highly coloured early B type stars (like the measures made by Trumpler) to wave-lengths of $10,000 \AA$.

At the joint meeting of Commission 28 and Commission 36 Prof. H. Shapley presided.

Prof. Shapley called attention to recent work by Whipple showing that the superposition of spectra of giant stars of all types in the proportions to be expected in the extragalactic nebulae, gives a composite spectrum with dwarf-like characteristics, as actually observed in these objects. There is a need for more spectrophotometric measures of line intensities and profiles in individual stars of our own system, in order that this work may be extended. Prof. H. H. Plaskett asked whether photographs of the spectrum of the Milky Way could be obtained to help in this work, but Dr van Maanen stated that this had been tried without success some years ago at Mt Wilson.

The absorption of light in extragalactic as well as galactic space was mentioned by Prof. H. H. Plaskett. Studies of the surface brightnesses of extragalactic nebulae would probably help in this problem.

Prof. Plaskett also pointed out that work is needed on the origin of the continuous spectrum in diffuse and planetary nebulae. The colour distribution should be measured in the ordinary region for studying the hydrogen Paschen continuous spectrum and in the region below $\lambda_{3600}$ for the Balmer continuous spectrum. Recent advances in technique, particularly the Utrecht work on ultraviolet colour standards, have facilitated measures to be made in that region. The Balmer decrement should also be measured. The observations suggested were particularly needed for investigation of the distribution of electron velocities, which is probably non-Maxwellian. Dr Zanstra and Prof. Eddington agreed that a nonMaxwellian distribution was to be expected, although they appeared to think the problem more complicated than as outlined by Prof. Plaskett. The importance of study of discontinuities in the continuous spectrum near the heads of the Balmer and Paschen series was emphasized by Dr Minnaert.

Dr Redman drew attention to the desirability of continuing interferometer work along lines followed by Fabry and later by Baade and Minkowski and their respective collaborators. Dr Zanstra emphasized this point; if possible, the interferometer should be used to determine small radial velocities (o to Io $\mathrm{km}$. sec.) in planetary nebulae, to supplement the work of Campbell and Moore. Dr van Maanen reported 
that interferometer work was in progress at Mt Wilson under Baade and Minkowski. Prof. Russell spoke concerning the great progress made, chiefly by Bowen, since the last I.A.U. meetings, in the elucidation of the spectra of diffuse and planetary nebulae. He suggested that interferometer observations would help also in this work.

\section{COMMISSION 29. (STELLAR SPECTRA.)}

\section{PRESIDENT: Prof. H. N. Russeil. \\ SECRETARY: Dr P. Swings.}

I. Le rapport distribué aux personnes présentes commence par un court aperçu des principaux travaux faits dans le domaine des spectres stellaires depuis l'assemblée précédente. Le Président demande si l'une ou l'autre personne désire suggérer des modifications ou compléments à cet exposé. Aucune observation n'est présentée.

2. Le rapport du sous-comité chargé de l'examen des critères de classification des spectres stellaires est ensuite mis en discussion. Une lettre de Mme PayneGaposchkin a été reçue à ce sujet; Mme Payne-Gaposchkin signale que des détails manquent dans le rapport du sous-comité; elle demande aussi que soient définis clairement les types $A_{7}$ et $K_{7}$ actuellement utilisés fréquemment, ainsi que les symboles $g$ et $d$ distinguant les étoiles géantes et naines.

Pour ce qui concerne le premier point, le président du sous-comité, M. W. S. Adams, insiste sur le fait que le rapport n'a jamais eu la prétention d'être un exposé complet; il est en fait destiné aux personnes qui débutent dans ce domaine et non aux astronomes spécialisés. Pour ce qui concerne les autres points de la lettre de Mme Payne-Gaposchkin, M. Russell estime que cela peut constituer une partie de la tâche à continuer par le sous-comité.

Mlle Cannon demande ce qu'est devenu le projet de publier des reproductions de spectres stellaires typiques. M. Adams indique la difficulté d'une telle réalisation pour des raisons d'échelles; le sous-comité espère d'ailleurs s'occuper de la question.

A l'unanimité, le rapport est adopté et il est décidé que le sous-comité continuera le travail et se chargera notamment de l'illustrer éventuellement au moyen de reproductions de spectres typiques.

3. Rapport du sous-comité chargé de la classification des étoiles de Wolf-Rayet. En l'absence de M. C. S. Beals, Président de ce sous-comité, M. H. H. Plaskett présente le rapport et signale combien la rédaction en a été difficile; avec $\mathrm{Mme}$ Payne-Gaposchkin, il serait d'avis que les intensités totales des bandes d'émission seraient utiles pour la classification des étoiles de Wolf-Rayet; la même opinion est exprimée par Mme Payne-Gaposchkin dans une lettre au Président.

Le Président insiste sur le fait que la question n'a pu être réglée aisément à temps, à cause de la mort tragique de $\mathrm{M}$. Waterfield qui était chargé d'obtenir des spectres d'étoiles de Wolf-Rayet de l'hémisphère sud. Il propose que le rapport de MM. C. S. Beals et H. H. Plaskett soit joint comme appendice et que le travail soit continué.

M. Shapley signale que durant ces derniers mois, un certain nombre de spectres très utiles ont été obtenus par le successeur de $\mathrm{M}$. Waterfield.

Après un échange de vues auquel prennent part MM. Shapley, Adams, H. H. Plaskett, J. S. Plaskett et le Président, il est unanimement admis que le rapport sera publié en appendice, que Mme Payne-Gaposchkin sera invitée à joindre un second appendice contenant ses remarques et que le travail sera continué par le sous-comité. 